\title{
The effect of alfalfa (Medicago sativa) silage chop length and inclusion rate within a total mixed ration on the ability of lactating dairy cows to cope with a short-term feed withholding and refeeding challenge
}

\author{
A. L. Thomson, D. J. Humphries, L. A. Crompton, and C. K. Reynolds ${ }^{1}$ \\ Sustainable Agriculture and Food Systems Research Division, Centre for Dairy Research, School of Agriculture, Policy and Development, \\ University of Reading, Whiteknights Road, Reading, RG6 6AR, United Kingdom
}

\begin{abstract}
The objectives of the study were (1) to test whether $6 \mathrm{~h}$ of feed deprivation followed by refeeding induces an acidosis challenge in dairy cattle and (2) to quantify the acidosis challenge mitigation potential of increased alfalfa silage concentration in the diet. Alfalfa silage constituted either 25 or $75 \%$ of forage dry matter (DM) replacing corn silage [low (LA) or high alfalfa (HA)] and was chopped to either 14 or $19 \mathrm{~mm}$ theoretical length [short (S) or long (L)]. Dietary treatments LAS, LAL, HAS, or HAL were offered to 4 rumen-cannulated Holstein dairy cattle (161 d in milk; 5th or 6th parity) in a $4 \times 4$ Latin square design study with 21 -d periods. Starch concentration was $69 \mathrm{~g} / \mathrm{kg}$ of DM higher for LA diets than HA diets. Feed was withheld for $6 \mathrm{~h}$ followed by ad libitum refeeding on d 18 of each period. Measurements of DM intake, milk yield and composition, rumen $\mathrm{pH}$, and eating and rumination behavior were taken on 1 baseline day, the challenge day, and 2 further recovery days. After refeeding, rumen $\mathrm{pH}$ was reduced in cows fed LA diets but not HA diets. Feeding LAL resulted in the greatest subclinical acidosis risk $(\mathrm{pH}<5.8$ for $355 \mathrm{~min}$ on the first recovery day). Animals fed LA produced $4.4 \mathrm{~L}$ less milk on the challenge day in comparison to baseline. It was concluded that short-term feed deprivation detrimentally affected rumen health and milk yield in dairy cattle normally fed ad libitum, but had no effect on DM intake or milk composition. Feeding alfalfa silage in place of corn silage mitigated acidosis risk due to interrupted feed supply, likely due to a combination of lower starch concentration in HA diets, greater effective fiber concentration, and higher buffering capacity of alfalfa relative to corn silage.
\end{abstract}

Key words: alfalfa, chop length, acidosis, feed withholding, rumen challenge

Received October 2, 2017.

Accepted January 2, 2018.

${ }^{1}$ Corresponding author: c.k.reynolds@reading.ac.uk

\section{INTRODUCTION}

Lactating dairy cow diets are often formulated to include a high concentration of rapidly fermented NFC as a source of energy to support milk production (Lechartier and Peyraud, 2011); however, such diets can also decrease rumen $\mathrm{pH}$ through greater rate of production of VFA (Allen, 1997). In circumstances where $\mathrm{pH}$ remains below 5.8 for 3 consecutive hours, a dairy cow is purported to suffer from SARA, a condition that can reduce milk yield and milk fat concentration (Plaizier et al., 2008). Dietary strategies to increase the resilience of dairy cattle to SARA include feeding forages with high buffering capacities (e.g., alfalfa, Medicago sativa) or increasing the concentration of physically effective fiber (peNDF) in the diet by lengthening forage chop length (McBurney et al., 1983; Zebeli et al., 2006). Physically effective fiber is defined as the NDF contained within particles that are longer than the critical particle size for rumen escape [which recent research suggests is 4 $\mathrm{mm}$, although it was historically defined as $1.18 \mathrm{~mm}$ (Oshita et al., 2004; Maulfair and Heinrichs, 2012)] and therefore can contribute to the rumen mat (Mertens, 2000). A lower rumen $\mathrm{pH}$ has also been linked with changes in cow feeding behavior and the adoption of coping mechanisms, including showing preferences for long particles in the diet (DeVries et al., 2008; Maulfair et al., 2013) or for supplementary hay (Kmicikewycz and Heinrichs, 2015).

Experimentally, the stability of rumen $\mathrm{pH}$ can be tested by induction of a rumen fermentation challenge. This is typically achieved through the addition of a large quantity of a rapidly degradable carbohydrate to the diet, such as cereal grains or alfalfa pellets (Krause and Oetzel, 2005; Colman et al., 2013). However, it is unclear whether such a method accurately replicates conditions that cause SARA and, furthermore, may not provide an appropriate model for evaluating dietary mitigation strategies. An alternative approach to instigate a rumen challenge is deprivation of feed for a period of several hours (Oetzel, 2007). A period of 
fasting is then followed by a period of overeating when access to feed is returned, termed refeeding (Chilibroste et al., 2007). Periods of feed deprivation lasting up to $6 \mathrm{~h}$ may be relatively common in a commercial setting; for instance, where insufficient feed or pasture is allocated, during feeding equipment failure, or when the animal's access to feed for routine processes such as milking or health checks is removed. However, relatively little is known about the severity of the effect of such events on rumen function and milk production. Studies in the literature have examined the effect of longer periods of fasting, such as 12 to $48 \mathrm{~h}$ (Chelikani et al., 2004; Oetzel, 2007; Toerien and Cant, 2007), that generally result in high levels of temporary milk yield loss; however, we are not aware of any studies that have examined the effects of shorter fasting periods in dairy cattle that would be more representative of commercial practice. Therefore, the aims of the present study were (1) to test whether $6 \mathrm{~h}$ of feed deprivation followed by refeeding induces an acidosis challenge and (2) to examine the effect of varying inclusion rate (IR) and chop length (CL) of alfalfa silage replacing corn silage in a TMR on resilience to a feed withholding and refeeding challenge.

\section{MATERIALS AND METHODS}

\section{Forage Harvesting and Clamp Sampling}

The present study formed part of a larger research trial that used the same dietary treatments and observed their effects on milk yield, DMI, diet digestibility, and rumen function under nonchallenging conditions in a larger cohort of cows and over a longer time period, as reported previously (Thomson et al., 2017a,b). In brief, alfalfa silage was harvested as a second cut crop at an estimated 10\% bloom in July 2014 and conserved in concrete-walled clamps. The crop was wilted for 48 $\mathrm{h}$ and ensiled, producing a high-DM $(576 \mathrm{~g} / \mathrm{kg}$ of fresh weight) silage. Two CL [long (L) and short (S)] were created from material collected in alternate swaths by altering the knife arrangement of the precision chop forage harvester (Claas Jaguar, Claas Group, Harsewinkel, Germany) from a theoretical chop length of 14 (shortest setting) to $19 \mathrm{~mm}$ (longest setting) that were ensiled in 2 adjacent clamps. An additive was applied (Axcool Gold containing Lactobacillus buchneri; $2 \mathrm{~L} / \mathrm{t}$; Biotal, Cardiff, UK) to prevent heating in the clamp. Samples for chemical composition analysis (Sciantec Analytical Services, Cawood, UK) were obtained using a clamp corer. A detailed analysis of the particle length profile of the silages produced (mean 14.3 and $9.0 \mathrm{~mm}$ for L and S, respectively) has been published previously (experiment 2; Thomson et al., 2017b). Corn
(Zea mays) silage for the study was taken from a commercial crop of mixed varieties harvested in autumn 2014 that was chopped by the forage harvester (Model FR700, New Holland Ltd., Turin, Italy; theoretical chop length of $18 \mathrm{~mm}$ ) and ensiled as described for the alfalfa clamps [geometric mean particle length of 10 mm determined using a Penn State particle separator (PSPS); Heinrichs, 2013].

\section{Diets}

Diets comprised a TMR with 50:50 ratio of forage to concentrate on a DM basis (Thomson et al., 2017a,b), in which the forage portion consisted of corn and alfalfa silage at IR (DM basis) of either 25:75 (high alfalfa; HA) or 75:25 (low alfalfa; LA), respectively. These treatments were combined with the 2 alfalfa silage CL in a $2 \times 2$ factorial arrangement to give 4 treatments (HAL, HAS, LAL, and LAS) that were formulated to be isonitrogenous (170 $\mathrm{g}$ of $\mathrm{CP} / \mathrm{kg}$ of $\mathrm{DM})$ and contain similar levels of NDF $(320 \mathrm{~g} / \mathrm{kg}$ of DM). The reduction in corn starch associated with the lower corn silage inclusion in HA diets was partially offset by increasing the concentration of corn meal (Table 1); however, for the experimental diets fed, starch concentration was still lower in the HA diets (Table 2).

\section{Animals}

Four multiparous Holstein dairy cows, previously prepared with rumen fistulae (Bar Diamond rumen cannula; Parma, ID), in mid-lactation (161 DIM, SE $\pm 23.1)$, weighing $739 \mathrm{~kg}(\mathrm{SE} \pm 13.9)$, and 7 to $9 \mathrm{yr}$ of age (5th or 6th parity), were randomly assigned to 1 of 4 initial treatments according to a $4 \times 4$ Latin square design balanced for carryover effects with 21 -d periods. All procedures were licensed and monitored by the UK Government's Home Office under the Animal (Scientific Procedures) Act 1986. The experimental design and replication employed was based on variance and expected treatment effects for key variables observed in previous studies (Reynolds et al., 2014). During adaptation weeks (wk 1 and 2 of each period), animals were housed in a cubicle yard and individually fed once daily for ad libitum intake (10\% refusals) through Insentec RIC feeders (Insentec B.V., Marknesse, the Netherlands). Continuous access to water was provided. From d 12 of each period, animals were housed and milked in individual tiestalls to facilitate sampling. Animals were allowed to acclimatize to the stalls for $3 \mathrm{~d}$ before sampling beginning on d 15 . While in tiestalls, animals were offered their daily feed allocation in 2 halves at 1000 and $1600 \mathrm{~h}$. Refusals were taken daily at $0930 \mathrm{~h}$. Between d 15 and 18, measurements of rumen func- 
tion under nonchallenging conditions were performed, including rumen VFA and ammonia concentrations, rumen $\mathrm{pH}$, rumen mat particle distribution, and fecal particle distribution, which have been reported previously (Thomson et al., 2017b). The feeding routine differed on d 18 of each period when a refeeding challenge was simulated (described below). While in tiestalls, each cow was also fitted with a rumination head collar (Itin+Hoch GmbH, Fütterungstechnik, Liestal, Switzerland) to measure eating and rumination behavior as described previously (Ruuska et al., 2016).

\section{Experimental Routine}

Baseline measurements of all variables were taken on d 16 of each period (other than rumen $\mathrm{pH}$, which was measured on d 15 because other measurements being

Table 1. Ingredients used in diet formulation

\begin{tabular}{|c|c|c|}
\hline \multirow[b]{2}{*}{ Ingredients, $\mathrm{g} / \mathrm{kg}$ of $\mathrm{DM}$} & \multicolumn{2}{|c|}{ Diet $^{1}$} \\
\hline & LA & HA \\
\hline Alfalfa silage $^{2}$ & 125 & 375 \\
\hline Corn silage ${ }^{3}$ & 375 & 125 \\
\hline \multicolumn{3}{|l|}{ Concentrate blend ${ }^{4}$} \\
\hline Cracked wheat & 80 & 80 \\
\hline Corn meal & 54 & 97 \\
\hline Unmolassed sugar beet feed & 40 & 40 \\
\hline Soy hulls & 82 & 108 \\
\hline Soybean meal & 100 & 65 \\
\hline Rapeseed meal & 100 & 65 \\
\hline Molasses & 10 & 10 \\
\hline Dicalcium phosphate & 5 & 5 \\
\hline Salt & 5 & 5 \\
\hline Dairy mineral ${ }^{5}$ & 10 & 10 \\
\hline Megalac $^{6}$ & 15 & 15 \\
\hline
\end{tabular}

${ }^{1} \mathrm{LA}=$ low-alfalfa diet; $\mathrm{HA}=$ high-alfalfa diet.

${ }^{2}$ Long chop alfalfa silage composition: $593 \mathrm{~g} / \mathrm{kg}$ of DM; $164 \mathrm{~g}$ of $\mathrm{CP} /$ $\mathrm{kg}$ of DM; $397 \mathrm{~g}$ of NDF/ $\mathrm{kg}$ of DM; $348 \mathrm{~g}$ of ADF $/ \mathrm{kg}$ of DM; $108 \mathrm{~g}$ of ash $/ \mathrm{kg}$ of DM; and $10 \mathrm{~g}$ of water-soluble carbohydrate $/ \mathrm{kg}$ of DM. Short chop alfalfa silage composition: $566 \mathrm{~g} / \mathrm{kg}$ of DM; $167 \mathrm{~g}$ of $\mathrm{CP} /$ $\mathrm{kg}$ of DM; $385 \mathrm{~g}$ of NDF $/ \mathrm{kg}$ of DM; $326 \mathrm{~g}$ of ADF $/ \mathrm{kg}$ of DM; $108 \mathrm{~g}$ of ash $/ \mathrm{kg}$ of DM; and $17 \mathrm{~g}$ of water-soluble carbohydrate $/ \mathrm{kg}$ of DM.

${ }^{3}$ Corn silage composition: $383 \mathrm{~g} / \mathrm{kg}$ of DM; $63 \mathrm{~g}$ of $\mathrm{CP} / \mathrm{kg}$ of DM; 387 $\mathrm{g}$ of NDF $/ \mathrm{kg}$ of DM; $223 \mathrm{~g}$ of ADF $/ \mathrm{kg}$ of DM; $37 \mathrm{~g}$ of ash $/ \mathrm{kg}$ of DM; $357 \mathrm{~g}$ of starch $/ \mathrm{kg}$ of $\mathrm{DM}$; and $25 \mathrm{~g}$ of water-soluble carbohydrate/ $\mathrm{kg}$ of DM.

${ }^{4} \mathrm{HA}$ concentrate composition: $911 \mathrm{~g} / \mathrm{kg}$ of DM; $199 \mathrm{~g}$ of $\mathrm{CP} / \mathrm{kg}$ of DM; $278 \mathrm{~g}$ of NDF $/ \mathrm{kg}$ of DM; $172 \mathrm{~g}$ of ADF $/ \mathrm{kg}$ of DM; $67 \mathrm{~g}$ of ash $/ \mathrm{kg}$ of $\mathrm{DM} ; 247 \mathrm{~g}$ of starch $/ \mathrm{kg}$ of DM; and $57 \mathrm{~g}$ of water-soluble carbohydrate/kg of DM. LA concentrate composition: $884 \mathrm{~g} / \mathrm{kg}$ of DM; $241 \mathrm{~g}$ of CP $/ \mathrm{kg}$ of DM; $272 \mathrm{~g}$ of NDF $/ \mathrm{kg}$ of DM; $171 \mathrm{~g}$ of ADF $/ \mathrm{kg}$ of DM; 71 $\mathrm{g}$ of ash $/ \mathrm{kg}$ of DM; $195 \mathrm{~g}$ of starch $/ \mathrm{kg}$ of DM; and $67 \mathrm{~g}$ of water-soluble carbohydrate $/ \mathrm{kg}$ of DM.

${ }^{5}$ Contained vitamin A $(400,000 \mathrm{IU} / \mathrm{kg})$, vitamin D $(80,000 \mathrm{IU} / \mathrm{kg})$, and vitamin $\mathrm{E}(2,000 \mathrm{IU} / \mathrm{kg})$, manganese $(2.2 \mathrm{~g} / \mathrm{kg})$, calcium $(230 \mathrm{~g} / \mathrm{kg})$, zinc $(5.2 \mathrm{~g} / \mathrm{kg})$, phosphorous $(20 \mathrm{~g} / \mathrm{kg})$, magnesium $(40 \mathrm{~g} / \mathrm{kg})$, sodium $(95 \mathrm{~g} / \mathrm{kg})$, copper $(1.2 \mathrm{~g} / \mathrm{kg})$, and selenium $(30 \mathrm{mg} / \mathrm{kg})$.

${ }^{6}$ Megalac rumen protected fat supplement (Volac International Ltd., Royston, UK). performed on d 16 have been reported separately). On d 18 of each period, refusals from the previous day were removed from the cows $1 \mathrm{~h}$ early $(0830 \mathrm{~h})$ to begin a period of fasting. Feed was withheld for $6 \mathrm{~h}$ until $1430 \mathrm{~h}$, when half the daily diet allocation was offered followed by the second half $2 \mathrm{~h}$ later at $1630 \mathrm{~h}$. On d 19 , refusal and feeding routine was returned to that of $d$ 17. To summarize, the timetable for wk 3 of each period was

- d 15: Basal rumen pH recorded (coinciding with sampling of rumen liquor, reported separately);

- d 16: Basal DMI, milk yield, and eating and rumination behavior measurements;

- d 17: Rest day with refusals removed $1 \mathrm{~h}$ early the following morning;

- d 18: Feed withheld until $1430 \mathrm{~h}$ followed by refeeding;

- d 19: Recovery d 1, original feeding routine resumed;

- d 20: Recovery d 2; and

- d 21: No measurements, rest allowed before diet change.

\section{Intake and Diet Analysis}

The weight and DM concentration of feed offered and refused were measured during d 14 to 21 of each period for each cow. A daily grab sample of each TMR and the TMR constituents was bulked across the sampling week for each diet in each period (16 samples in total). Dry matter concentration of feed was determined by oven drying at $100^{\circ} \mathrm{C}$ for $24 \mathrm{~h}$. Samples of the TMR constituents for each diet in each period were stored frozen at $-20^{\circ} \mathrm{C}$ until analyzed for DM, $\mathrm{N}$ (using the macro-Kjeldahl method; AOAC 954.01, AOAC International, 2000), ash (by combustion at $500^{\circ} \mathrm{C}$ for 16 h), NDF and ADF (expressed inclusive of residual ash; Robertson and Van Soest, 1981; Mertens et al., 2002), starch (Fuller, 1967; Macrae and Armstrong, 1968), and water-soluble carbohydrates as described previously (Reynolds et al., 2014; Kliem et al., 2017). Concentrations ( $\mathrm{g} / \mathrm{kg}$ of $\mathrm{DM}$ ) of $\mathrm{CP}, \mathrm{NDF}, \mathrm{ADF}$, ash, starch, and water-soluble carbohydrates in each TMR were calculated based on constituent inclusion rates. A sample of each TMR from each period was analyzed for particle size distribution using a PSPS (sieve apertures measuring 19, 8 , and $4 \mathrm{~mm}$ in diameter and a bottom pan). A DM correction for material retained on each sieve was obtained (Thomson et al. 2017a). Average particle size of the sample was calculated as described previously (Heinrichs, 2013) and peNDF was calculated as the proportion of particles (DM corrected) greater than the threshold length $(4,8$, or $19 \mathrm{~mm})$ multiplied 
Table 2. The chemical and physical composition of 4 TMR containing a high (HA) or low (LA) concentration of alfalfa silage at a long (L) or short (S) chop length (Thomson et al., 2017b)

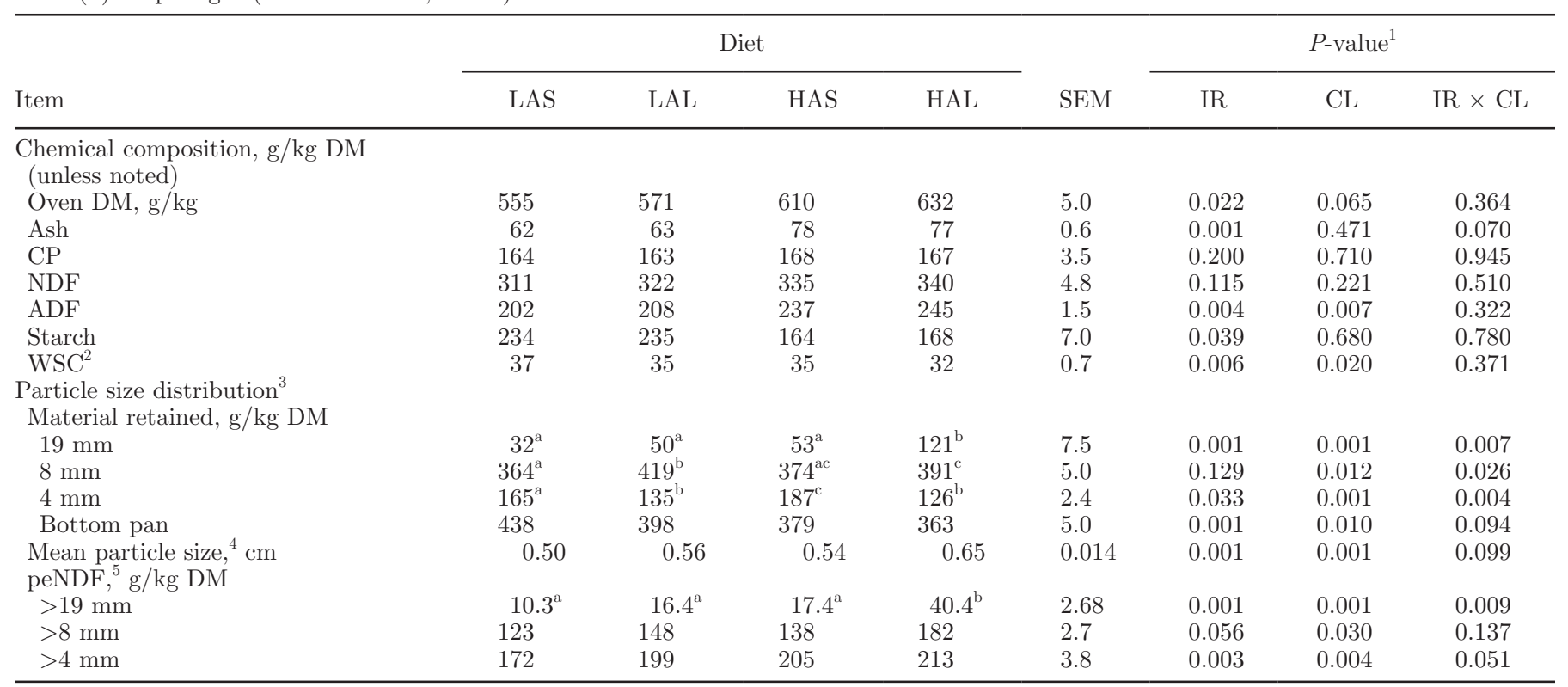

${ }^{\mathrm{a}-\mathrm{c}}$ Values within a row with different superscripts differ significantly at $P<0.05$.

${ }^{1} \mathrm{IR}=$ inclusion rate; $\mathrm{CL}=$ chop length; $\mathrm{IR} \times \mathrm{CL}=$ interaction between $\mathrm{IR}$ and $\mathrm{CL}$.

${ }^{2} \mathrm{WSC}=$ water-soluble carbohydrate.

${ }^{3}$ Particle size distribution measured using a Penn State Particle Separator with 3 sieves: 19, 8, and 4 mm diameter.

${ }^{4}$ Mean particle size was determined using the recommended equation of Penn State University (Heinrichs, 2013).

${ }^{5}$ Physically effective neutral detergent fiber (peNDF) determined as the proportion of particles in the TMR greater than the threshold length multiplied by the NDF concentration of the TMR (Mertens, 1997).

by the NDF concentration of the diet (Mertens, 1997; Farmer et al., 2014). The chemical and physical composition of the diets is shown in Table 2 for reference but has been discussed in detail previously (Thomson et al., 2017b).

Milk Yield and Composition. Cows were milked twice daily at 0630 and $1630 \mathrm{~h}$, and milk samples, preserved using potassium dichromate, were analyzed for fat, protein, casein, lactose, urea, and SCC by mid-infrared spectroscopy on a CombiFoss machine (National Milk Laboratories, Chippenham, Wiltshire, UK). The CombiFoss machine combines both the Fossomatic 5000 and Milkoscan 6000 (both Foss, Hillerød, Denmark) and uses the entire mid-infrared wavelength spectrum. Morning and afternoon milk samples were scanned separately. Only data from d 16 (baseline), 18 (challenge), 19 (recovery d 1), and 20 (recovery d 2) were statistically analyzed.

Rumen $\boldsymbol{p H}$. An indwelling $\mathrm{pH}$ meter (Sentix 41-3 probe, WTW Trifthof, Weilheim, Germany) attached to a weight $(200 \mathrm{~g})$ and connected to the rumen cannula using nylon cord $(50 \mathrm{~cm})$ was placed within the rumen of each animal for $24 \mathrm{~h}$, beginning just before feeding $(0930 \mathrm{~h})$ on d 15 of each period until refusals were removed at $0930 \mathrm{~h}$ on $\mathrm{d} 16$, to establish baseline patterns of rumen $\mathrm{pH}$; the $\mathrm{pH}$ meter was inserted again at $0830 \mathrm{~h}$ on $\mathrm{d} 18$ (challenge day), remaining within the rumen until $0930 \mathrm{~h}$ on $\mathrm{d} 21$. The probe was calibrated before every insertion by immersion in solutions of $\mathrm{pH}$ 4 and 7. After use, the probe was reimmersed in the calibration solutions and any drift was calculated as the given value subtracted from the true $\mathrm{pH}$ of the solution. Drift greater than $0.3 \mathrm{pH}$ units was considered the upper threshold for inclusion; however, no readings greater than this value were found in the present study and therefore all data were included. The $\mathrm{pH}$ probe was attached to a data logger (ph340i, WTW Trifthof) with readings recorded every $10 \mathrm{~min}$. Time spent at $\mathrm{pH}$ $<6.2$ and $<5.8$ were calculated for each day for each cow in each period. Readings were then averaged over each hour for further analysis, beginning on the hour for baseline, and recovery d 1 and 2, and at the half hour mark for challenge day to coincide with feeding times. Any measurements within the first hour of insertion $(0830$ to $0930 \mathrm{~h})$ were not included in statistical analysis due to differences in the start time of each cow.

\section{Statistical Analysis}

Average daily data starting at morning feeding, 1000 $\mathrm{h}$, were calculated for 4 phases (days) of wk 3 : baseline (d 15/16), challenge (d 18), recovery 1 (d 19), and re- 
covery 2 (d 20). Averages for each cow, treatment, and day combination were analyzed to determine fixed effects of period, alfalfa IR, alfalfa CL, day (as a repeated measure) and their interactions (IR $\times \mathrm{CL}, \mathrm{IR} \times$ day, $\mathrm{CL} \times$ day, and $\mathrm{IR} \times \mathrm{CL} \times$ day), and random effects of cow using mixed models procedures of SAS (version 9.4, SAS Institute Inc., Cary, NC). The SLICE option was used to show treatment effects for each day. Least squares means for each treatment and effects of IR, CL, and IR $\times$ CL interactions within each day are presented separately. Within each treatment, means for challenge or recovery days were compared with the baseline value for that treatment using the PDIFF option within the LSMEANS statement of the Mixed procedure. For measurements of eating time and relative rumen $\mathrm{pH}$ within each day, the same model was used except day was replaced with hour (a repeated measure) and each day was analyzed separately. The covariance structure giving the best fit (out of compound symmetry, compound symmetry heterogeneous, unstructured, or spatial power) was chosen for each variable using the Bayesian information criterion. Compound symmetry and spatial power were the most common structures of best fit.

For rumen $\mathrm{pH}$, a baseline value for each hour of a 24-h period (starting at morning feeding, d 15, 1000 h) was taken for each cow on each treatment that was then subtracted from the hourly mean at the same time point for each subsequent phase to analyze and present each hourly value relative to baseline. The data were transformed in this way to ensure the magnitude of any effects could be compared between animals with differing baseline rumen $\mathrm{pH}$ levels. For example, the nadir $\mathrm{pH}$ observed during baseline varied between cows from 5.76 to 6.22 (mean of all treatments for each animal), and basal daily mean rumen $\mathrm{pH}$ similarly ranged from 6.48 to 6.76 between animals. Therefore, presenting data as time below a certain threshold was judged to be of lesser importance than $\mathrm{pH}$ change relative to baseline. A mean of relative $\mathrm{pH}$ for each day was also analyzed (with the challenge day subdivided into fast and refeeding) to determine fixed effects of period, alfalfa IR, alfalfa CL, and IR $\times$ CL interaction, and random effects of cow using mixed models procedures with each day and subphase tested separately. For rumen $\mathrm{pH}$ parameters, we found no effects of period; therefore it was judged that recovery time was sufficient in between challenges to prevent carryover effects.

Effects of treatment on diet chemical and physical composition were analyzed separately using values for each bulked diet sample in each period $(\mathrm{n}=16$ bulked samples originating from d 15-21). Fixed effects of period, alfalfa IR, alfalfa CL, IR $\times$ CL interaction and random effect of cow were also used using mixed models procedure of SAS with period as a repeated measure.

\section{RESULTS}

\section{Baseline Treatment Effects}

The effect of treatment on diet chemical composition and particle size in the present study (Table 2) have been reported previously (Thomson et al., 2017a,b). Briefly, the concentration of starch was $69 \mathrm{~g} / \mathrm{kg}$ of DM greater in LA diets than in HA diets by design $(P<$ 0.04 ), whereas ADF concentration was $36 \mathrm{~g} / \mathrm{kg}$ of DM greater in HA diets $(P<0.01)$. Increasing $\mathrm{CL}$ from $\mathrm{S}$ to $\mathrm{L}$ increased the proportion of particles retained on both the 8- and 19-mm sieves of the PSPS by 36 and $43 \mathrm{~g} / \mathrm{kg}$ of $\mathrm{DM}$, respectively, whereas it reduced the proportion that was retained on the $4-\mathrm{mm}$ sieve and in the bottom pan (all $P<0.02$ ). Both greater IR and greater CL of alfalfa increased or tended to increase peNDF concentrations using 4, 8, and $19 \mathrm{~mm}$ threshold lengths $(P<0.06)$ relative to a low IR and a short CL.

We found no effect of diet on daily mean rumen $\mathrm{pH}$, for which the average across all treatments was 6.36 (Table 3), or on daily time spent at less than $\mathrm{pH} 6.2$ or $\mathrm{pH} 5.8$, nor were there any time points during the baseline day in which we noted an effect of treatment on rumen $\mathrm{pH}$. Following feeding at baseline, rumen $\mathrm{pH}$ showed a downwards trend, reaching a nadir between 9 and $13 \mathrm{~h}$ after morning feeding followed by a return to prefeeding levels between 15 and $22 \mathrm{~h}$ postfeeding (Figure 1a). Baseline eating patterns showed an increase in time spent eating $(20-40 \mathrm{~min} / \mathrm{h})$ in the first hour after fresh feed was offered (at both 1000 and $1600 \mathrm{~h}$ ), followed by a reduction in time spent eating in the second hour postfeeding to roughly $10 \mathrm{~min} / \mathrm{h}$, a rate that was sustained throughout the daytime hours (Figure 1b). Between 13 and $19 \mathrm{~h}$ postfeeding, $<5 \mathrm{~min} / \mathrm{h}$ of eating occurred, corresponding to the rise in rumen $\mathrm{pH}$ shown in Figure 1a. Dry matter intake, milk yield, milk composition, and the yield of milk solids showed no effect of treatment during the baseline phase (Table 4). Both daily mean time spent eating (Table 5) and transient eating patterns were similar for all dietary treatments at baseline. Cows fed HAL diets had more daily mean rumination chews and spent more time ruminating per day than cows fed either LAL or HAS, whereas cows fed LAS had an intermediate number of ruminating chews (IR $\times \mathrm{CL} ; P<0.04$ ). Cows fed HAL diets also showed a tendency to spend the greatest time ruminating per day compared with other dietary treatments $(\mathrm{IR} \times \mathrm{CL} ; P<0.07)$. Hourly patterns of rumination indicate a level profile of rumination for all treatments throughout the day, with 10 to 30 min spent ruminating each hour (Figure 1c). 
Table 3. Mean relative rumen $\mathrm{pH}$ of lactating dairy cows fed a TMR containing a high (HA) or low (LA) concentration of alfalfa silage at a long (L) or short (S) chop length before, during, and following a rumen challenge that involved a 6-h fast followed by a refeeding challenge

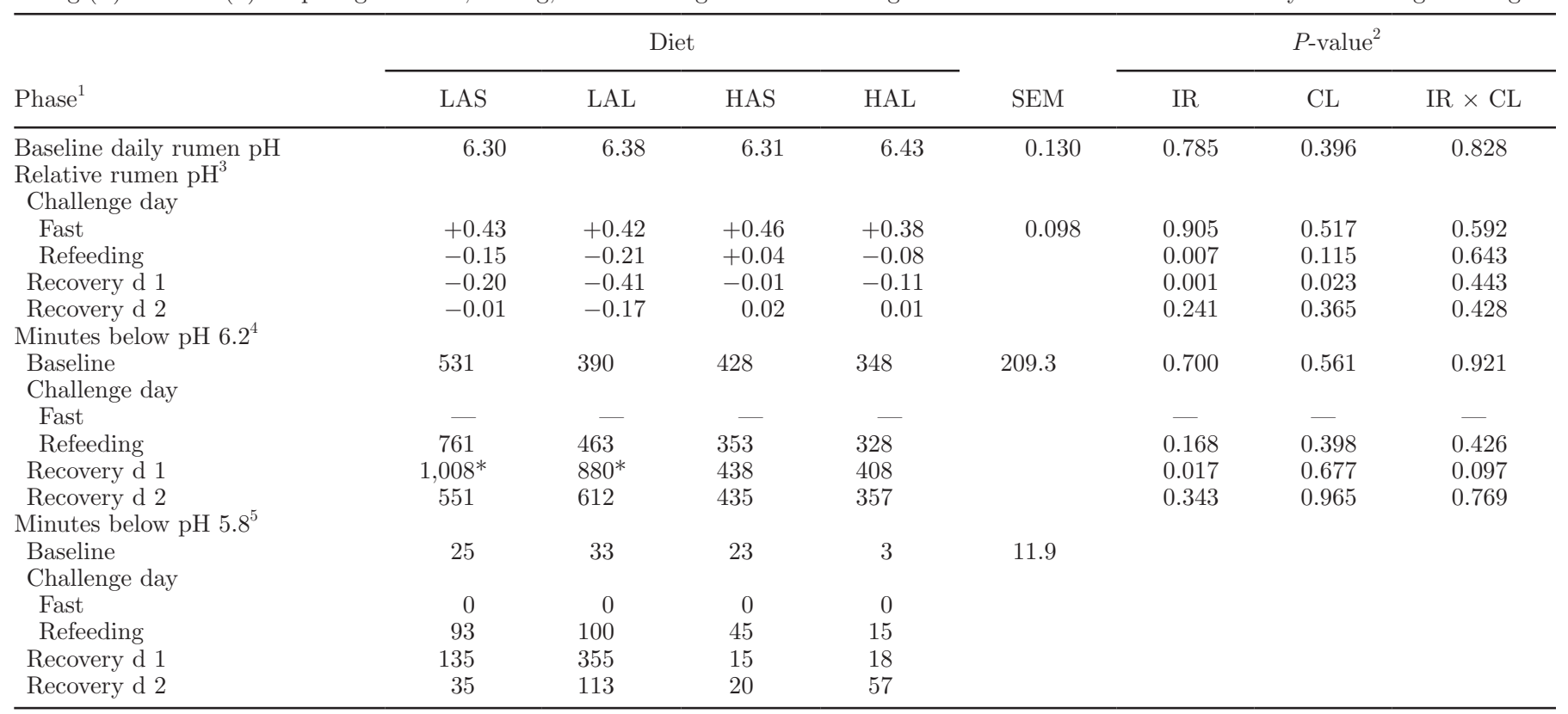

${ }^{1}$ The fast period combines measurements from 0930 until $1430 \mathrm{~h}$ on the day of the challenge, during which time animals were not allowed to access feed (note, the start of the feed withdrawal was $0830 \mathrm{~h}$; however, the time taken to insert rumen pH probes meant that data for this hour was incomplete and not included in the analysis). The refeeding period combines measurements from $1430 \mathrm{~h}$ on the day of the challenge until $0930 \mathrm{~h}$ the following morning. The subsequent two 24 -h periods are termed recovery $\mathrm{d} 1$ and recovery $\mathrm{d} 2$ that both begin at $1000 \mathrm{~h}$.

${ }^{2} \mathrm{IR}=$ inclusion rate; $\mathrm{CL}=$ chop length; $\mathrm{IR} \times \mathrm{CL}=$ interaction between $\mathrm{IR}$ and $\mathrm{CL}$.

${ }^{3}$ Relative rumen $\mathrm{pH}$ calculated hourly as rumen $\mathrm{pH}$ measurement minus the corresponding baseline measurement (Thomson et al., 2017b) at the same hour of the day for each cow on each treatment in each phase.

${ }^{4}$ All cows spent either low or no time below pH 6.2 during the fast subphase, and therefore this subphase was removed from statistical analysis to prevent non-normality of the remaining data set.

${ }^{5}$ For minutes below pH 5.8 a large number of values were 0 , and therefore the data did not display a normal distribution nor could a meaningful transformation be achieved. Thus, data are presented as arithmetic means.

*Value differs significantly $(P<0.05)$ from a baseline value for that treatment (not applicable to relative rumen $\mathrm{pH}$ ).

\section{Challenge Effect on Rumen $\mathrm{pH}$ and Eating Patterns}

Relative rumen $\mathrm{pH}$ increased steadily during the feed withholding period for all diets (Figure 2a). We observed no effect of treatment on the mean relative $\mathrm{pH}$ (Table 3) nor at any individual time points over the fasting phase. At the peak of the fasting phase, mean rumen $\mathrm{pH}$ across the treatments ranged from 6.8 to 7.2 . A steep fall in rumen $\mathrm{pH}$ on all treatments occurred with the refeeding event. Over the first hour after refeeding, relative rumen $\mathrm{pH}$ in cows fed the LAL diet decreased to the baseline level in comparison to the other 3 diets $(P<0.03)$; in the LAS, HAL, and HAS diets, relative $\mathrm{pH}$ remained elevated above baseline levels until $2 \mathrm{~h}$ after refeeding, which coincided with the second offering of feed. At 8 to $12 \mathrm{~h}$ after refeeding, rumen $\mathrm{pH}$ of cows fed LA diets fell to lower levels than HA relative to their baseline values (IR effects $P<0.04$ ), whereas HAS remained closer to baseline than HAL $(\mathrm{IR} \times \mathrm{CL}$ interaction; $P<0.04$ ). Cows fed HAS diets maintained a rumen $\mathrm{pH}$ that was close to baseline $\mathrm{pH}$ throughout the refeeding period, $0.04 \mathrm{pH}$ units higher than baseline over the entire refeeding phase. Cows fed LA diets had a rumen $\mathrm{pH} 0.16 \mathrm{pH}$ units lower, on average, over the refeeding phase than HA diets relative to their own baseline values $(P<0.008$; Table 3$)$ and spent, on average, $97 \mathrm{~min}$ at $\mathrm{pH}<5.8$ compared with $30 \mathrm{~min}$ for cows fed HA diets.

Cows spent a greater proportion of time eating in the $3 \mathrm{~h}$ following refeeding than during the same period after the initial feed was offered at baseline (57 vs. $29 \%$ of each hour was spent eating in $0-3 \mathrm{~h}$ postfeeding respectively; Figure 2b). At $4 \mathrm{~h}$ after refeeding, eating intensity reduced for cows fed all diets, although at $6 \mathrm{~h}$ after refeeding cows fed the LAS diet again spent a high proportion of time eating in comparison to cows fed other diets $(P<0.01)$. Following this, cows on all diets continued to eat at a fluctuating rate between 0 and $20 \mathrm{~min} / \mathrm{h}$ (Figure 2b). Rumination pattern indicated a slightly larger reduction in rumination between 0 and $4 \mathrm{~h}$ after refeeding than at mealtimes on other days during the observation period for cows on all treat- 
4186

$\begin{array}{lll}\cdots \cdots \cdot \text {. LAS } & ---- \text { LAL } & --\cdot \text { HAS } \\ * \text { IR effect } & \text { - CL effect } & \text { - IR*CL effect }\end{array}$

(a)

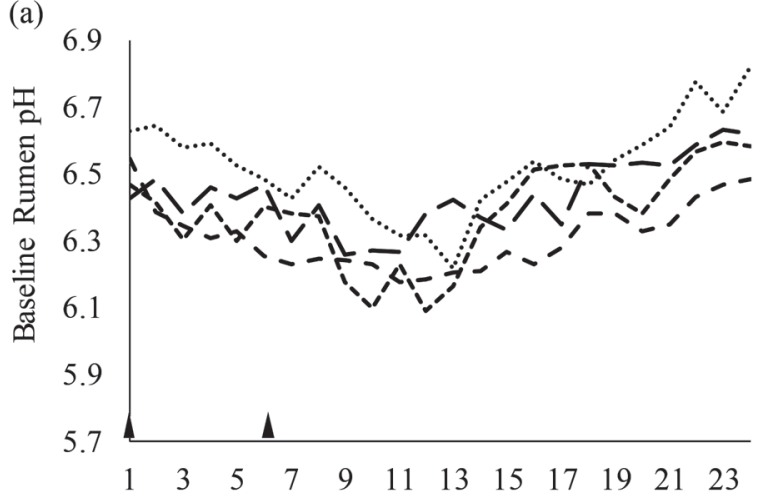

(b)

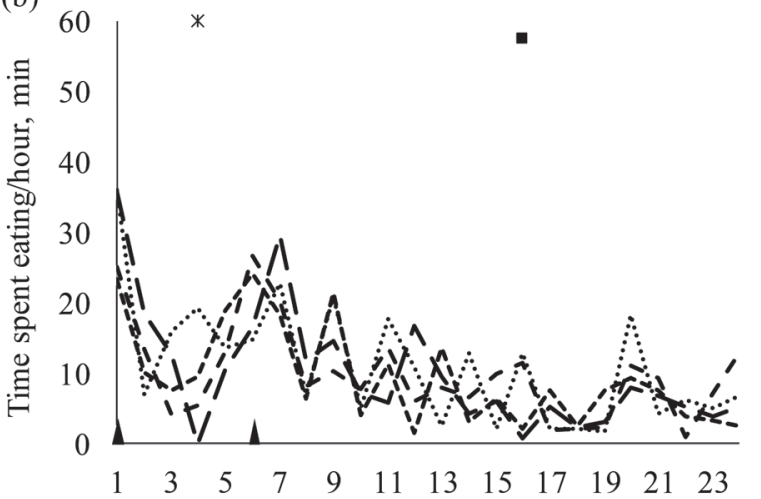

(c)

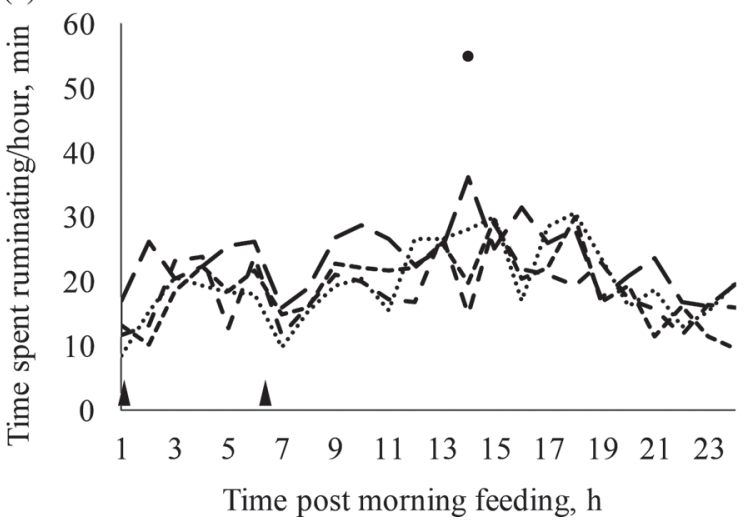

Figure 1. Hourly mean (a) rumen pH (Thomson et al., 2017b), (b) time spent eating, and (c) time spent ruminating of lactating dairy cows fed a TMR containing a high (HA) or low (LA) concentration of alfalfa silage at a long $(\mathrm{L})$ or short $(\mathrm{S})$ chop length over a 24-h baseline period beginning at $1000 \mathrm{~h}$ (hour 1). Baseline values were measured over a single 24 -h period $2 \mathrm{~d}$ (for eating pattern) or $3 \mathrm{~d}$ (for rumen $\mathrm{pH}$ ) before a feed deprivation or refeeding challenge was administered. Black triangles indicate time points at which half a daily allocation of feed was offered. Hours at which a significant effect of alfalfa inclusion rate (IR), alfalfa chop length (CL), or their interaction occured, analyzed using Mixed Models procedure of SAS (version 9.4; SAS Institute Inc., Cary, NC), are marked. ments. In the hour before refeeding, cows fed LA diets ruminated very little $(<5 \mathrm{~min})$ in comparison to cows fed HA that continued to ruminate for between 15 and 25 min during the hour $(P<0.04)$.

\section{Recovery from the Rumen Challenge}

On recovery $\mathrm{d} 1$, the rumen $\mathrm{pH}$ of all cows recovered close to baseline levels before morning feeding. However, postfeeding, the rumen $\mathrm{pH}$ of cows fed LA diets again decreased relative to their baseline values, leading to multiple hours with effects of IR. At $31 \mathrm{~h}$ after refeeding the rumen $\mathrm{pH}$ of cows fed LAS diets returned to basal values, whereas cows fed LAL diets continued to show reduced relative rumen $\mathrm{pH}$ until $36 \mathrm{~h}$ after refeeding (IR $\times \mathrm{CL}$ interactions $P<0.04$ ). Cows fed HAS diets continued to show a rumen $\mathrm{pH}$ pattern close to baseline whereas cows fed HAL diets were marginally lower than baseline values (Figure 2a). Mean relative rumen $\mathrm{pH}$ for the recovery $\mathrm{d} 1$ phase demonstrated that cows fed LA and $\mathrm{L}$ diets had reduced relative $\mathrm{pH}$ in comparison to HA and S diets (effect of IR $P<0.001$; effect of CL $P<0.03$ ), which was also reflected in cows fed LA spending longer at $\mathrm{pH}<5.8$ than cows fed HA.

On recovery d 2 , we found no significant differences in relative rumen $\mathrm{pH}$ between treatments or any hours in which treatment differences occurred, although the relative rumen $\mathrm{pH}$ of cows fed LAL diets continued to be the lowest of the 4 treatments and, on average, 0.17 $\mathrm{pH}$ units below baseline values for that diet (Table 3). Over both recovery days, eating and rumination patterns appeared similar to those observed at baseline. Some fluctuation led to significant effects on time spent eating and ruminating during these days, but overall differences were slight and not sustained.

\section{Induction of SARA}

Taking the definition of SARA to be a period of 3 consecutive hours where rumen $\mathrm{pH}$ is less than 5.8 , we observed 6 bouts of SARA within the data set, of which 2 bouts were in the same cow when fed the LAS diet and the remaining 4 were in 3 cows when fed the LAL diet (with 1 cow experiencing 2 separate bouts on this diet). Of these 6 bouts of SARA, 2 occurred on the day of the challenge (1 LAS and $1 \mathrm{LAL}$ ) and 4 occurred on recovery d 1 (1 LAS and 3 LAL). No episodes of SARA were observed in cows fed HA diets.

\section{Challenge Effect on Intake and Milk Production}

On the day of the challenge, DMI was similar to that consumed on baseline day (Table 4), as was daily mean time spent eating and ruminating (Table 5) despite 
Table 4. Daily mean intake, milk production, and milk composition of lactating dairy cows fed a TMR containing a high (HA) or low (LA) concentration of alfalfa silage at a long $(\mathrm{L})$ or short $(\mathrm{S})$ chop length before, during, and following a 6-h fast followed by a refeeding challenge

\begin{tabular}{|c|c|c|c|c|c|c|c|c|}
\hline \multirow[b]{2}{*}{ Item $^{1}$} & \multicolumn{4}{|c|}{ Diet } & \multirow[b]{2}{*}{ SEM } & \multicolumn{3}{|c|}{$P$-value ${ }^{2}$} \\
\hline & LAS & LAL & HAS & HAL & & IR & CL & $\mathrm{IR} \times \mathrm{CL}$ \\
\hline \multicolumn{9}{|l|}{$\mathrm{DMI}, \mathrm{kg} / \mathrm{d}$} \\
\hline Baseline day & 25.5 & 21.3 & 22.5 & 24.4 & \multirow[t]{4}{*}{1.44} & 0.998 & 0.359 & 0.133 \\
\hline Challenge day & 25.2 & 23.7 & 24.5 & 23.6 & & 0.764 & 0.352 & 0.810 \\
\hline Recovery d 1 & 25.3 & 21.5 & 23.1 & 22.2 & & 0.548 & 0.085 & 0.251 \\
\hline Recovery d 2 & 23.1 & 19.6 & 23.7 & 21.8 & & 0.289 & 0.049 & 0.130 \\
\hline Challenge day & $27.2^{*}$ & $25.8^{*}$ & 25.9 & 27.3 & \multirow{3}{*}{5.89} & 0.985 & 0.994 & 0.994 \\
\hline Recovery d 1 & 31.9 & 29.5 & 29.0 & 30.8 & & 0.879 & 0.954 & 0.978 \\
\hline Recovery d 2 & 30.9 & 28.2 & 29.0 & 27.0 & & 0.775 & 0.664 & 0.962 \\
\hline \multicolumn{9}{|l|}{ Milk fat, $\mathrm{g} / \mathrm{kg}$} \\
\hline Baseline day & 32.6 & 35.2 & 35.3 & 33.2 & \multirow[t]{3}{*}{3.04} & 0.766 & 0.832 & 0.305 \\
\hline Challenge day & 38.7 & 38.4 & 34.0 & 34.8 & & 0.218 & 0.948 & 0.638 \\
\hline Recovery d 1 & 34.7 & 35.3 & 35.8 & 35.8 & & 0.588 & 0.817 & 0.939 \\
\hline \multicolumn{9}{|c|}{ Milk fat yield, $\mathrm{kg} / \mathrm{d}$} \\
\hline Recovery d 2 & 1.12 & 1.01 & 1.01 & 1.07 & 0.208 & 0.892 & 0.898 & 0.968 \\
\hline \multicolumn{9}{|c|}{ Milk protein, $\mathrm{g} / \mathrm{kg}$} \\
\hline Baseline day & 31.3 & 31.5 & 30.9 & 30.9 & \multirow[t]{4}{*}{1.16} & 0.602 & 0.923 & 0.952 \\
\hline Challenge day & 31.4 & 31.0 & 30.2 & 29.5 & & 0.209 & 0.583 & 0.585 \\
\hline Recovery d 1 & 30.3 & 30.8 & 30.2 & 29.1 & & 0.364 & 0.764 & 0.637 \\
\hline Recovery d 2 & 30.6 & 30.4 & 30.5 & 29.1 & & 0.546 & 0.490 & 0.755 \\
\hline \multicolumn{9}{|c|}{ Milk protein yield, $\mathrm{kg} / \mathrm{d}$} \\
\hline Baseline day & 0.99 & 0.95 & 0.84 & 0.87 & \multirow[t]{4}{*}{0.173} & 0.440 & 0.996 & 0.869 \\
\hline Challenge day & $0.85^{*}$ & $0.80^{*}$ & 0.77 & 0.80 & & 0.808 & 0.954 & 0.990 \\
\hline Recovery d 1 & 0.96 & 0.91 & 0.87 & 0.89 & & 0.740 & 0.920 & 0.982 \\
\hline Recovery d 2 & 0.94 & 0.87 & 0.88 & 0.75 & & 0.571 & 0.549 & 0.857 \\
\hline
\end{tabular}

\footnotetext{
${ }^{\mathrm{a}, \mathrm{b}}$ Values within a row with different superscripts differ significantly at $P<0.05$.

${ }^{1}$ Baseline data were collected on d 16 and the challenge day was d 18 (starting at $1000 \mathrm{~h}$ ) of each period, during which animals spent $4.5 \mathrm{~h}$ of the day fasting (after a 1.5-h period during which refusals were removed early to make a total fast of $6 \mathrm{~h}$ ) and a 17.5-h period in which feed was offered ad libitum. Recovery d 1 and 2 were the subsequent 24-h periods (d 19 and 20, respectively, both beginning $1000 \mathrm{~h}$ ).

${ }^{2} \mathrm{IR}=$ inclusion rate; $\mathrm{CL}=$ chop length; $\mathrm{IR} \times \mathrm{CL}=$ interaction between $\mathrm{IR}$ and $\mathrm{CL}$.

*Value differs significantly $(P<0.05)$ from a baseline value for that treatment.
}

the pattern of eating during the day being altered as described earlier. A numerical decline in intake was observed between the challenge day and recovery day 2 for cows fed LAL and HAL diets, resulting in animals fed $\mathrm{L}$ eating $2.7 \mathrm{~kg} / \mathrm{d}$ less than animals fed $\mathrm{S}$ on recovery day $2(P<0.05)$.

Milk yield was reduced in cows fed LAS and LAL diets on challenge day relative to milk yield at baseline $(P<0.05)$ by 4.5 and $4.3 \mathrm{~kg}$, respectively, although yield was not significantly lower than that of cows fed the HA diets on the challenge day. The reduction in milk yield on LA diets on this day also led to significant reductions in milk protein yield compared with baseline for these treatments. On recovery d 1 and 2, milk yield for all treatments was not statistically different $(P>$ $0.05)$ from baseline levels. Concentrations of milk protein were unaffected by treatment and day. The milk fat yield of cows fed LAS and HAL diets on recovery d 2 was higher than baseline $(P<0.05)$, and furthermore the milk fat yield for HAL cows on that day was greater than that of any other dietary treatment $(\mathrm{IR} \times \mathrm{CL} ; P$ $<0.04)$.

\section{DISCUSSION}

\section{Effect of a Refeeding Challenge on Eating Patterns and Rumen $\mathrm{pH}$}

During the fasting phase, before refeeding, we observed increased rumen $\mathrm{pH}$ for all animals, likely because of rumen VFA being absorbed and not replaced due to a lack of substrate for fermentation, and perhaps as an effect of salivation while the animals were waiting for feed to be offered. In support of this, cows were shown to continue ruminating during the fasting period. Following refeeding, animals exhibited a 3 -h period in which a high proportion of time was spent eating across all treatments in comparison to 
Table 5. Eating and rumination behavior of lactating dairy cows fed a TMR containing a high (HA) or low (LA) concentration of alfalfa silage at a long $(\mathrm{L})$ or short $(\mathrm{S})$ chop length before, during, and following a 6-h fast followed by a refeeding challenge

\begin{tabular}{|c|c|c|c|c|c|c|c|c|}
\hline \multirow[b]{2}{*}{ Item $^{1}$} & \multicolumn{4}{|c|}{ Diet } & \multirow[b]{2}{*}{ SEM } & \multicolumn{3}{|c|}{$P$-value ${ }^{2}$} \\
\hline & LAS & LAL & HAS & HAL & & IR & CL & $\mathrm{IR} \times \mathrm{CL}$ \\
\hline Baseline day & 17.8 & 12.1 & 12.8 & 14.0 & \multirow[t]{4}{*}{2.56} & 0.509 & 0.351 & 0.392 \\
\hline Challenge day & 16.2 & 12.0 & 15.4 & 14.5 & & 0.707 & 0.283 & 0.626 \\
\hline Recovery d 1 & 15.4 & 9.8 & 13.5 & 11.4 & & 0.950 & 0.120 & 0.410 \\
\hline Recovery d 2 & 14.4 & 11.1 & 11.9 & 15.0 & & 0.791 & 0.961 & 0.605 \\
\hline Challenge day & 250 & 217 & 267 & 227 & \multirow{3}{*}{35.0} & 0.681 & 0.271 & 0.665 \\
\hline Recovery d 1 & 241 & 177 & 249 & $189^{*}$ & & 0.768 & 0.073 & 0.305 \\
\hline Recovery d 2 & 229 & 184 & 217 & 222 & & 0.703 & 0.551 & 0.808 \\
\hline \multicolumn{9}{|c|}{ Ruminating chews $\times 10^{3} / \mathrm{d}$} \\
\hline Baseline day & $27.6^{\mathrm{ab}}$ & $27.5^{\mathrm{a}}$ & $24.2^{\mathrm{a}}$ & $35.4^{\mathrm{b}}$ & \multirow[t]{3}{*}{3.01} & 0.414 & 0.052 & 0.038 \\
\hline Challenge day & 28.7 & 26.2 & 26.1 & 34.2 & & 0.336 & 0.319 & 0.124 \\
\hline Recovery d 1 & 31.0 & 29.0 & 27.8 & 32.0 & & 0.958 & 0.691 & 0.673 \\
\hline Recovery d 2 & 494 & 438 & 478 & 533 & 47.1 & 0.414 & 0.991 & 0.591 \\
\hline
\end{tabular}

${ }^{\mathrm{a}, \mathrm{b}}$ Values within a row with different superscripts differ significantly at $P<0.05$.

${ }^{1}$ Baseline data were collected on d 16 and the challenge day was d 18 (starting at $1000 \mathrm{~h}$ ) of each period, during which animals spent $4.5 \mathrm{~h}$ of the day fasting (after a 1.5-h period during which refusals were removed early to make a total fast of $6 \mathrm{~h}$ ) and a 17.5-h period in which feed was offered ad libitum. Recovery d 1 and 2 were the subsequent 24-h periods (d 19 and 20, respectively, both beginning $1000 \mathrm{~h}$ ).

${ }^{2} \mathrm{IR}=$ inclusion rate; $\mathrm{CL}=$ chop length; $\mathrm{IR} \times \mathrm{CL}=$ interaction between $\mathrm{IR}$ and $\mathrm{CL}$.

*Value differs significantly $(P<0.05)$ from a baseline value for that treatment.

the baseline day ( 57 vs. $29 \%$ of each hour was spent eating from $0-3 \mathrm{~h}$ postfeeding respectively; Figure $2 \mathrm{~b}$ ). An increase in eating intensity following feed deprivation is consistent with the findings of other studies (Patterson et al., 1998; Oetzel, 2007) and has been linked with low rumen fill before refeeding (Gregorini et al., 2007). This overeating episode resulted in a rapid decrease in rumen $\mathrm{pH}$, such that $3 \mathrm{~h}$ after refeeding animals had reached the same rumen $\mathrm{pH}$ as observed $7 \mathrm{~h}$ after feeding on the baseline day. We attributed this accelerated decline in rumen $\mathrm{pH}$ to acid load from the ingested feed and from VFA produced from fermentation of the same. Furthermore, high feed intake in a short time-period would have increased the supply of rapidly degraded starch and sugars to the microbial population, especially within the LA diet that contained a greater concentration of starch from corn silage. Total VFA concentration in the rumen is dependent on the rate at which VFA are produced in comparison to the rate at which VFA can be absorbed through the ruminal epithelium, be neutralized by saliva, or are removed from the rumen by passage. Various absorption mechanisms facilitate VFA removal from the rumen; however, the most predominant are bicarbonate-dependent transport (Aschenbach et al., 2011) and passive diffusion (Chibisa et al., 2016). For the latter, a low VFA concentration in the rumen, such as that created by short-term feed deprivation, would reduce VFA removal rate initially until a sufficient diffusion gradient was established. Simultaneously, recent research suggests that such conditions are likely to also favor increased production rate of VFA by microbes that benefit from a diffusion gradient that swiftly removes VFA from their boundary layer (Russell et al., 2009; Mason and Stuckey, 2016). Therefore, the swift decline in rumen $\mathrm{pH}$ observed is likely to be a combined effect of increased microbial productivity combined with reduced ability to remove VFA from the rumen through absorption. Another longer-term study also noted a reduction in epithelial absorption rate during and after feed restriction that was attributed to reduced blood flow due to feed deprivation (e.g., $5 \mathrm{~d}$ of feed restriction followed by refeeding; Zhang et al., 2013); however, this is unlikely to be the case in our study, where feed was only withheld for $6 \mathrm{~h}$. Few previous studies examined withholding and refeeding TMR. Studies have examined effects in grazing animals (Chilibroste et al., 2007), but data are still lacking on rumen kinetics to explain the mechanisms underpinning responses to such a challenge, and further work is required to fully understand responses in TMR-fed animals. 

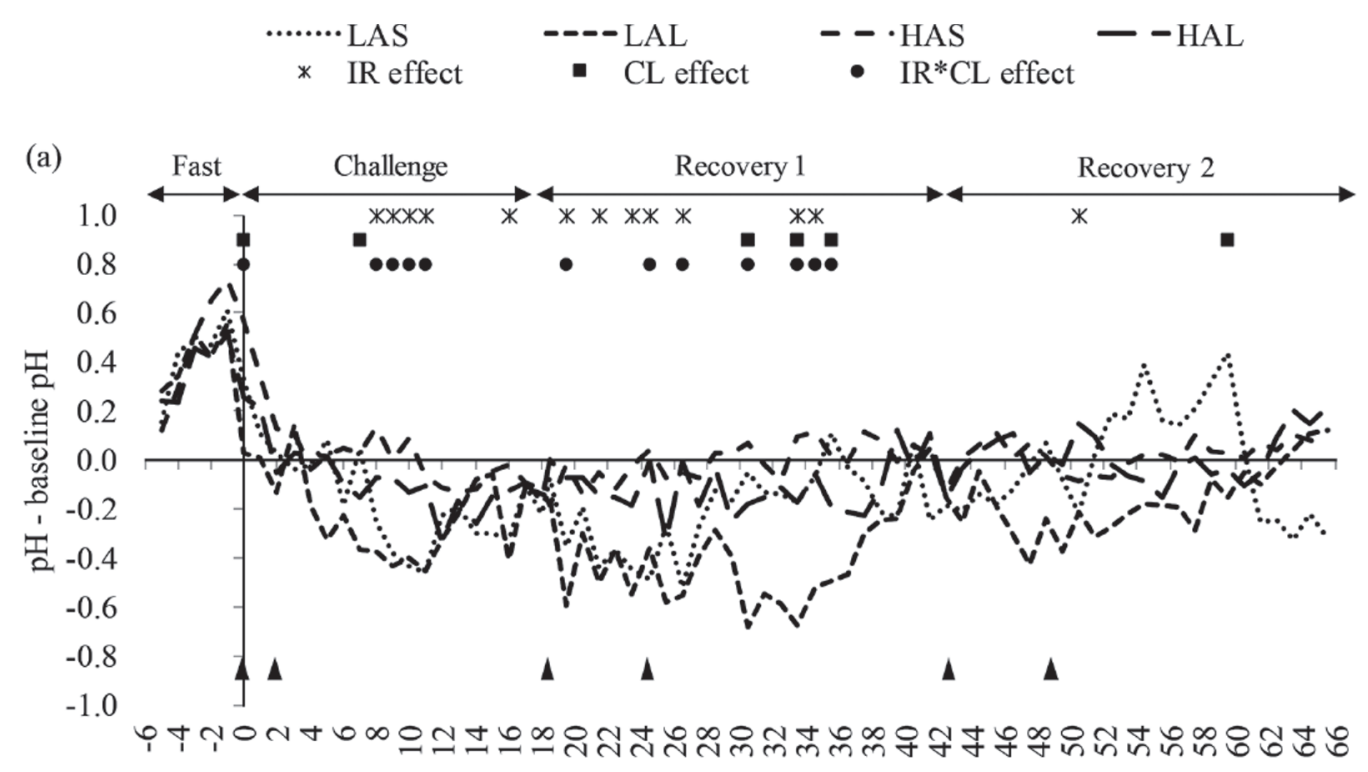

(b)

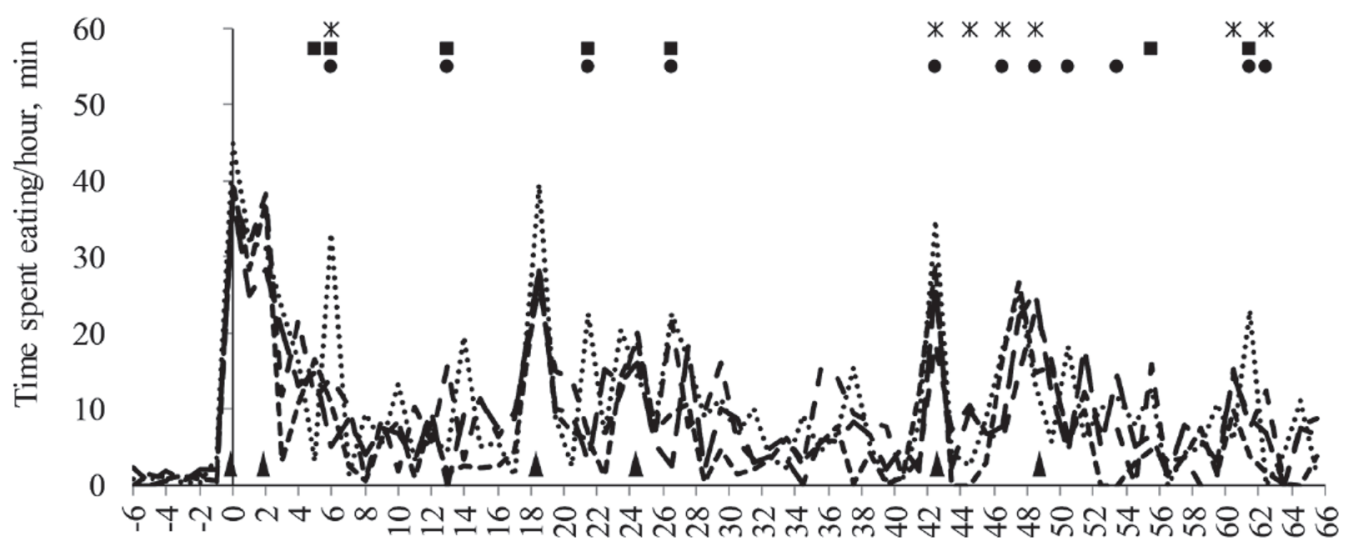

(c)

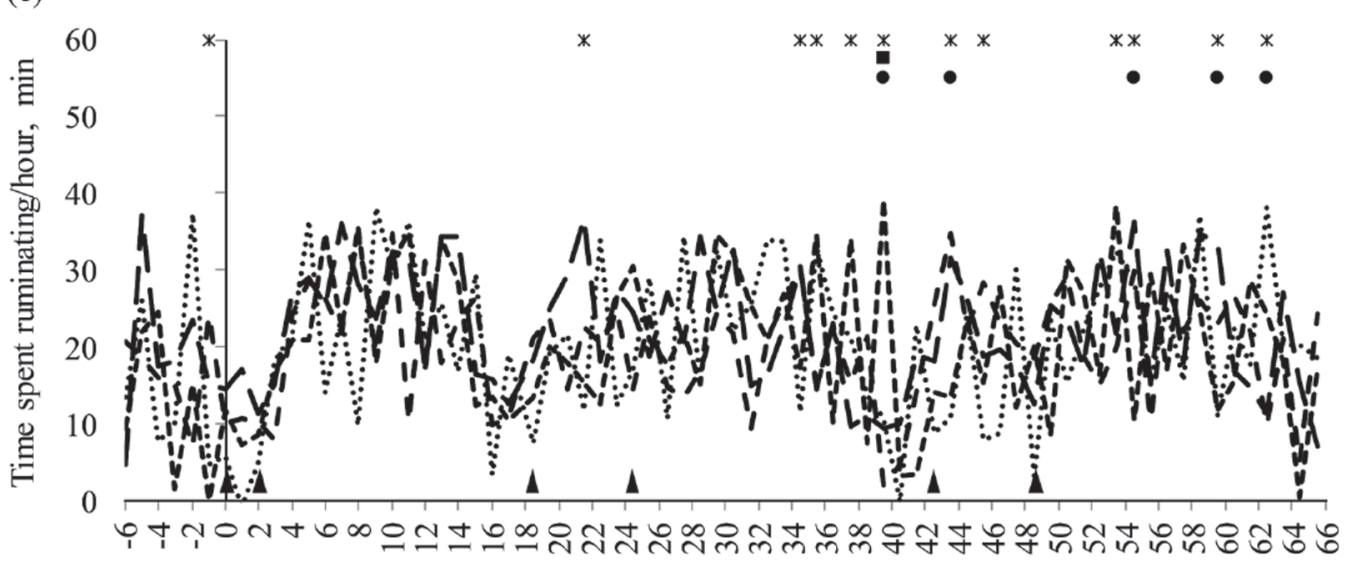

Time pre/post refeeding, $\mathrm{h}$

Figure 2. Hourly mean (a) relative rumen $\mathrm{pH}$, (b) time spent eating, and (c) time spent ruminating of lactating dairy cows fed a TMR containing a high (HA) or low (LA) concentration of alfalfa silage at a long (L) or short (S) chop length over a 72 -h period beginning at $0830 \mathrm{~h}$ on $\mathrm{d} 18$ of the period, when feed was withheld for $6 \mathrm{~h}$ followed by a refeeding challenge at $1430 \mathrm{~h}$. The hour beginning $1430 \mathrm{~h}$ is represented by 0 on the $\mathrm{x}$ axis. Black triangles indicate time points at which half a daily allowance of feed was offered. Hours at which we noted a significant effect of alfalfa inclusion rate (IR), alfalfa chop length (CL), or their interaction, analyzed using Mixed Models procedure of SAS (version 9.4; SAS Institute Inc., Cary, NC), are marked. 
Despite the reduced window of time when animals were allowed access to feed on the challenge day (18.5 $\mathrm{h}$ ), we found no difference in the quantity of feed consumed or total minutes spent eating in comparison to baseline days, again highlighting that eating rate postrefeeding was increased in comparison to basal eating rate. Milk yield was reduced on the day of the challenge for all diets, and significantly so for LA diets, which might indicate a carryover effect of the fasting period for these diets or that the increased rate of feed consumption after refeeding reduced the efficiency of energy capture from the diet. Concentrations of fat and protein within the milk were largely unaffected, other than an unexpected rise in milk fat concentration seen on recovery d 2 in both the LAS and HAL diets; however, this is likely to be due to slightly reduced milk yield on these treatments, as total fat yield was unaffected. It should also be noted that using a single day as a baseline value may not have fully accounted for day-to-day variation in our study.

\section{Acidosis Mitigation Potential of the Dietary Treatments}

In the present study, cows fed diets comprising a high IR of alfalfa silage were less affected by the rumen challenge than those with a low IR, despite no difference in rumen $\mathrm{pH}$ profile between the diets at baseline. Alfalfa silage provided more effective fiber (Table 2) to the diet than the corn silage and has also been reported previously to have a higher cation exchange capacity than corn (McBurney et al., 1983); therefore, a combination of these 2 factors could explain the increased ability of the cows to buffer against low rumen $\mathrm{pH}$. Furthermore, alfalfa often contains a higher proportion of indigestible, lignified stem in comparison to other forages that may reduce rumen passage rate and maintain rumen fill for longer, providing a better environment for continued microbial activity and facilitating a slow rate of VFA production in the rumen during the period of feed deprivation (Dewhurst et al.., 2003). In support of this, the present study showed that cows fed HA diets spent more time ruminating during the fast period than those fed LA. This may have enhanced the rate of microbial adaptation to refeeding, reduced any disruption of epithelial function, and therefore reduced negative effects on milk yield. The LA diets also contained a higher concentration of starch that would have contributed to reduced rumen $\mathrm{pH}$ at refeeding. The difference in starch concentration between the 2 diets may also have altered utilization of dietary nutrients, particularly nitrogen. We observed no incidence of SARA in cows fed HA diets, confirming that feeding alfalfa at the higher IR of $375 \mathrm{~g} / \mathrm{kg}$ diet of DM, and consequently feeding less corn silage and starch, was successful at mitigating acidosis risk in comparison to the lower inclusion rate. Milk loss in cows fed LA diets on the day of the challenge $(4.4 \mathrm{~kg} / \mathrm{d})$ was a decrease of $14.3 \%$ compared with baseline yield, which represents a cost to the farmer if animals were regularly fasted for similar periods ( $6 \mathrm{~h}$ continuous). Furthermore, the work of Dohme et al. (2008) suggests the severity of acidosis can increase where challenges are repeated in quick succession, although this was not evident in our study, as we observed no significant or numerical $(P>$ 0.2 ) effect of period on time spent at $\mathrm{pH}<6.2$. This is likely due methodological differences, as Dohme et al. (2008) induced challenges $14 \mathrm{~d}$ apart, as opposed to $21 \mathrm{~d}$ in the present study, and the effect of the challenges imposed were greater (using $4 \mathrm{~kg}$ of barley grain consumed within $1 \mathrm{~h}$ to induce acidosis) in their study, with nadir $\mathrm{pH}$ in the range of 5.13 to 5.53 versus 5.41 to 6.22 observed on recovery d 1 in our study. Furthermore, Dohme et al. (2008) also noted increased severity of subsequent acidosis challenges when cows were in early lactation as opposed to mid-lactation.

Evidence from jaw movement monitors in the present study confirmed that the long chop length increased rumination activity as would be expected; however, animals fed diets containing L chop alfalfa silage had lower ruminal $\mathrm{pH}$ on average on recovery $\mathrm{d} 1$ than animals fed S, with those fed LAL diets having the greatest and most prolonged reduction in ruminal $\mathrm{pH}$ in comparison to the other diets. In this regard, our findings contrast with previously published work that suggested a positive correlation between rumen $\mathrm{pH}$ and peNDF concentration (Zebeli et al., 2006), which was attributed to increased rumination supplying more saliva to the rumen, although these relationships were generated from studies where no feed withholding and refeeding challenge was applied. Lengthening chop length can negatively affect diet uniformity and allow increased sorting against longer particles, which would contain the most peNDF (Leonardi and Armentano, 2003); however, this is unlikely to explain the lower rumen $\mathrm{pH}$ of cows on $\mathrm{L}$ diets on recovery $\mathrm{d} 1$, as animals have previously been shown to increase selection of longer particles in response to a rumen challenge (DeVries et al., 2008). The beneficial effect of peNDF is thought to be the result of increased stimulation of rumination producing saliva to buffer the rumen, and, in line with this, HAL diets did increase rumination; however, we did not observe the same effect in the other diets, including LAL, where the concentration of peNDF was lower. Longer particles would have required rumination to aid digestion after ingestion; however, in our study rumination was reduced during the refeeding event while eating was prioritized, an effect that has 
also been observed in previous refeeding work (Chilibroste et al., 2007), meanwhile smaller forage particles and concentrates can be broken down without the need for further rumination chewing. This delay in rumination due to overeating may have reduced the ability of animals fed LAL to digest the forage portion of the diet. It is also possible that fiber digestion was impaired as a result of the low-pH conditions affecting microbial populations (Grant and Mertens, 1992). Reductions in DMI in animals fed the long CL diets on both recovery d 1 and 2 relative to those fed short CL diets (a difference that was not observed at baseline) also supports this explanation, as reducing fiber digestibility of dietary alfalfa has previously been linked to reduced appetite (Getachew et al., 2011; Fustini et al., 2017), likely due to increased feeling of satiety. However, if fiber digestion was reduced, the lack of an effect on milk composition suggests the effect was short-lived. Based on the negative effect of increasing peNDF provision through increased chop length, it is likely the mitigation effect of high alfalfa IR was attributable to the buffering capacity of alfalfa, increased rumen fill during the feed withholding phase, and reduced diet starch concentration rather than any effect of peNDF per se.

In the LAL diet, effects of the challenge continued throughout recovery d 1 despite a return to baseline feeding patterns, with DMI also reduced for this diet on recovery $\mathrm{d} 2$. The timeline is similar to that observed previously in the literature (Oetzel, 2007), where a cow faced with a 12-h fast followed by a refeeding challenge took $60 \mathrm{~h}$ for rumen $\mathrm{pH}$ to return to prefast levels. The extended number of days over which significant effects were seen despite no further challenges being applied highlights the need for rumen $\mathrm{pH}$ to be observed over several days when investigating induced SARA experimentally.

\section{CONCLUSIONS}

We concluded that a relatively short fast $(6 \mathrm{~h})$ followed by a refeeding event, in which a day's allocation of feed equal to the prefast level was offered ad libitum, was sufficient to induce SARA in 4 out of 8 observations where low-alfalfa diets were fed. However, a high rate of alfalfa inclusion within the diet combined with a lower dietary starch concentration mitigated the acidosis risk, and was particularly effective when the alfalfa silage was chopped to a shorter length. We attribute this mitigation effect to (1) buffering capacity provided by the alfalfa, (2) less degradable alfalfa fractions providing rumen substrate during the fast, and (3) reduced dietary starch concentration rather than increased effective fiber provision, as a longer particle length led to greater reductions in rumen $\mathrm{pH}$ after refeeding. Milk lost from cows fed diets with lower inclusion rates of alfalfa would represent a significant financial loss if such a refeeding challenge were to occur regularly, highlighting the need to ensure uniformity of feeding routines in ad libitum TMR feeding systems for dairy cows on a day-to-day basis.

\section{ACKNOWLEDGMENTS}

Funding for the present study was provided by the Agriculture and Horticulture Development Board's Dairy Division (AHDB Dairy, Stoneleigh, UK) as part of the Soils, Forage and Grassland Partnership. Thanks are given to Marcus Clauss of the University of Zurich (Zurich, Switzerland) for kindly loaning rumination monitoring equipment and to Marie Dittmann (University of Reading) for assisting in its usage. Further thanks go to the technical staff at the Centre for Dairy Research (Arborfield, UK) for their many inputs, including C. Green, P. Kirton, and D. Cockman.

\section{REFERENCES}

Allen, M. S. 1997. Relationship between fermentation acid production in the rumen and the requirement for physically effective fiber. J. Dairy Sci. 80:1447-1462. https://doi.org/10.3168/jds.S0022 -0302(97)76074-0.

AOAC International. 2000. Official Methods of Analysis. 17th ed. AOAC Int., Washington, DC.

Aschenbach, J. R., G. B. Penner, F. Stumpff, and G. Gabel. 2011. Ruminant nutrition symposium: Role of fermentation acid absorption in the regulation of ruminal pH. J. Anim. Sci. 89:1092-1107. https://doi.org/10.2527/jas.2010-3301.

Chelikani, P. K., J. D. Ambrose, D. H. Keisler, and J. J. Kennelly. 2004 Effect of short-term fasting on plasma concentrations of leptin and other hormones and metabolites in dairy cattle. Domest. Anim. Endocrinol. 26:33-48. https://doi.org/10.1016/j.domaniend.2003 .08 .003 .

Chibisa, G. E., K. A. Beauchemin, and G. B. Penner. 2016. Relative contribution of ruminal buffering systems to $\mathrm{pH}$ regulation in feedlot cattle fed either low- or high-forage diets. Animal 10:11641172. https://doi.org/10.1017/S1751731115002888.

Chilibroste, P., P. Soca, D. A. Mattiauda, O. Bentancur, and P. H. Robinson. 2007. Short term fasting as a tool to design effective grazing strategies for lactating dairy cattle: A review. Aust. J. Exp. Agric. 47:1075-1084. https://doi.org/10.1071/ea06130.

Colman, E., E. Khafipour, B. Vlaeminck, B. De Baets, J. C. Plaizier, and V. Fievez. 2013. Grain-based versus alfalfa-based subacute ruminal acidosis induction experiments: Similarities and differences between changes in milk fatty acids. J. Dairy Sci. 96:4100-4111. https://doi.org/10.3168/jds.2012-6109.

DeVries, T. J., F. Dohme, and K. A. Beauchemin. 2008. Repeated ruminal acidosis challenges in lactating dairy cows at high and low risk for developing acidosis: Feed sorting. J. Dairy Sci. 91:3958 3967. https://doi.org/10.3168/jds.2008-1347.

Dewhurst, R. J., W. J. Fisher, J. K. S. Tweed, and R. J. Wilkins. 2003. Comparison of grass and legume silage for milk production. 1. Production responses with different levels of concentrate. J. Dairy Sci. 86:2598-2611.

Dohme, F., T. J. DeVries, and K. A. Beauchemin. 2008. Repeated ruminal acidosis challenges in lactating dairy cows at high and low risk for developing acidosis: Ruminal pH. J. Dairy Sci. 91:35543567. https://doi.org/10.3168/jds.2008-1264. 
Farmer, E. R., H. A. Tucker, H. M. Dann, K. W. Cotanch, C. S. Mooney, A. L. Lock, K. Yagi, and R. J. Grant. 2014. Effect of reducing dietary forage in lower starch diets on performance, ruminal characteristics, and nutrient digestibility in lactating Holstein cows. J. Dairy Sci. 97:5742-5753.

Fuller, K. W. 1967. Automated determination of sugars. Pages 57-61 in Automation in Analytical Chemistry. European Technicon Symposia, Paris, France, 2-4 November 1966. Mediad Incorporated, New York, NY.

Fustini, M., A. Palmonari, G. Canestrari, E. Bonfante, L. Mammi, M. T. Pacchioli, G. C. J. Sniffen, R. J. Grant, K. W. Cotanch, and A. Formigoni. 2017. Effect of undigested neutral detergent fiber content of alfalfa hay on lactating dairy cows: Feeding behavior, fiber digestibility, and lactation performance. J. Dairy Sci. 100:4475-4483. https://doi.org/10.3168/jds.2016-12266.

Getachew, G., A. M. Ibanez, W. Pittroff, A. M. Dandekar, M. McCaslin, S. Goyal, P. Reisen, E. J. DePeters, and D. H. Putnam. 2011. A comparative study between lignin down regulated alfalfa lines and their respective unmodified controls on the nutritional characteristics of hay. Anim. Feed Sci. Technol. 170:192-200. https://doi.org/10.1016/j.anifeedsci.2011.09.009.

Grant, R. J., and D. R. Mertens. 1992. Development of buffer systems for ph control and evaluation of ph effects on fiber digestion in vitro. J. Dairy Sci. 75:1581-1587.

Gregorini, P., S. A. Gunter, C. A. Masino, and P. A. Beck. 2007. Effects of ruminal fill on short-term herbage intake rate and grazing dynamics of beef heifers. Grass Forage Sci. 62:346-354. https://doi .org/10.1111/j.1365-2494.2007.00589.x

Heinrichs, A. J. 2013. The Penn State Particle Separator. Penn State Extension. Accessed Nov. 15, 2016. http://extension.psu .edu/animals/dairy/nutrition/forages/forage-quality-physical/ separator.

Kliem, K. E., D. J. Humphries, C. K. Reynolds, R. Morgan, and D. I. Givens. 2017. Effect of oilseed type on milk fatty acid composition of individual cows, and also bulk tank milk fatty acid composition from commercial farms. Animal 11:354-364. https://doi.org/ 10.1017/S1751731116001403.

Kmicikewycz, A. D., and A. J. Heinrichs. 2015. Effect of corn silage particle size and supplemental hay on rumen $\mathrm{pH}$ and feed preference by dairy cows fed high-starch diets. J. Dairy Sci. 98:373-385. https://doi.org/10.3168/jds.2014-8103.

Krause, K. M., and G. R. Oetzel. 2005. Inducing subacute ruminal acidosis in lactating dairy cows. J. Dairy Sci. 88:3633-3639. https:// doi.org/10.3168/jds.S0022-0302(05)73048-4.

Lechartier, C., and J. L. Peyraud. 2011. The effects of starch and rapidly degradable dry matter from concentrate on ruminal digestion in dairy cows fed corn silage-based diets with fixed forage proportion. J. Dairy Sci. 94:2440-2454.

Leonardi, C., and L. E. Armentano. 2003. Effect of quantity, quality, and length of alfalfa hay on selective consumption by dairy cows. J. Dairy Sci. 86:557-564. https://doi.org/10.3168/jds.S0022 -0302(03)73634-0.

Macrae, J. C., and D. G. Armstrong. 1968. Enzyme method for determination of alpha-linked glucose polymers in biological materials. J. Sci. Food Agric. 19:578-581. https://doi.org/10.1002/jsfa .2740191006

Mason, P. M., and D. C. Stuckey. 2016. Biofilms, bubbles and boundary layers - A new approach to understanding cellulolysis in anaerobic and ruminant digestion. Water Res. 104:93-100. https:// doi.org/10.1016/j.watres.2016.07.063.

Maulfair, D. D., and A. J. Heinrichs. 2012. Review: Methods to measure forage and diet particle size in the dairy cow. Prof. Anim. Sci. 28:489-493.

Maulfair, D. D., K. K. McIntyre, and A. J. Heinrichs. 2013. Subacute ruminal acidosis and total mixed ration preference in lactating dairy cows. J. Dairy Sci. 96:6610-6620. https://doi.org/10.3168/ jds.2013-6771.

McBurney, M. I., P. J. Vansoest, and L. E. Chase. 1983. Cationexchange capacity and buffering capacity of neutral-detergent fibers. J. Sci. Food Agric. 34:910-916. https://doi.org/10.1002/jsfa .2740340903
Mertens, D. R. 1997. Creating a system for meeting the fiber requirements of dairy cows. J. Dairy Sci. 80:1463-1481.

Mertens, D. R. 2000. Physically effective NDF and its use in dairy rations explored. Feedstuffs April 2010; 10:11-14.

Mertens, D. R., M. Allen, J. Carmany, J. Clegg, A. Davidowicz, M. Drouches, K. Frank, D. Gambin, M. Garkie, B. Gildemeister, D. Jeffress, C. S. Jeon, D. Jones, D. Kaplan, G. N. Kim, S. Kobata, D. Main, X. Moua, B. Paul, J. Robertson, D. Taysom, N. Thiex, J. Williams, and M. Wolf. 2002. Gravimetric determination of amylase-treated neutral detergent fiber in feeds with refluxing in beakers or crucibles: Collaborative study. J. AOAC Int. 85:1217-1240.

Oetzel, G. 2007. Sub-acute ruminal acidosis in dairy herds: Physiology, pathophysiology, milk fat response, and nutritional management. Pages 89-119 in Proceedings of the 40th Meeting of the American Association of Bovine Practitioners, September 17, 2007, Vancouver, CA. American Association of Bovine Practitioners, Ashland, $\mathrm{OH}$.

Oshita, T., K. Nonaka, S. Kume, and T. Nakui. 2004. Effects of forage type on particle size distribution of ruminal digesta and faeces of non-lactating cows fed high quality forage. Livest. Prod. Sci. 91:107-115. https://doi.org/10.1016/j.livprodsci.2004.07.015.

Patterson, D. M., D. A. McGilloway, A. Cushnahan, C. S. Mayne, and A. S. Laidlaw. 1998. Effect of duration of fasting period on shortterm intake rates of lactating dairy cows. Anim. Sci. 66:299-305.

Plaizier, J. C., D. O. Krause, G. N. Gozho, and B. W. McBride. 2008 Subacute ruminal acidosis in dairy cows: The physiological causes, incidence and consequences. Vet. J. 176:21-31. https://doi.org/10 $.1016 / j . t v j l .2007 .12 .016$.

Reynolds, C. K., D. J. Humphries, P. Kirton, M. Kindermann, S. Duval, and W. Steinberg. 2014. Effects of 3-nitrooxypropanol on methane emission, digestion, and energy and nitrogen balance of lactating dairy cows. J. Dairy Sci. 97:3777-3789. https://doi.org/ 10.3168/jds.2013-7397.

Robertson, J. B., and P. J. Van Soest. 1981. The detergent system of analysis and its application to human foods. Pages 123-158 in The Analysis of Dietary Fiber in Food. W. James and O. Theander, ed. Marcel Decker Inc., New York, NY.

Russell, J. B., R. E. Muck, and P. J. Weimer. 2009. Quantitative analysis of cellulose degradation and growth of cellulolytic bacteria in the rumen. FEMS Microbiol. Ecol. 67:183-197. https://doi.org/ 10.1111/j.1574-6941.2008.00633.x.

Ruuska, S., S. Kajava, M. Mughal, N. Zehner, and J. Mononen. 2016 Validation of a pressure sensor-based system for measuring eating, rumination and drinking behaviour of dairy cattle. Appl. Anim. Behav. Sci. 174:19-23. https://doi.org/10.1016/j.applanim.2015.11 .005 .

Thomson, A. L., D. J. Humphries, A. K. Jones, and C. K. Reynolds. 2017a. The effect of varying proportion and chop length of alfalfa silage in a corn silage-based total mixed ration on diet digestibility and milk yield in dairy cattle. Animal 11:2211-2219. https://doi .org/10.1017/S175173111700129X.

Thomson, A. L., D. J. Humphries, K. E. Kliem, M. T. Dittmann, and C. K. Reynolds. 2017b. Effects of replacing corn silage with alfalfa silage and alfalfa silage chop length on rumen function and milk fatty acid composition. J. Dairy Sci. 100:7127-7138. https://doi .org/10.3168/jds.2017-12914.

Toerien, C. A., and J. P. Cant. 2007. Duration of a severe feed restriction required to reversibly decrease milk production in the highproducing dairy cow. Can. J. Anim. Sci. 87:455-458.

Zebeli, Q., M. Tafaj, H. Steingass, B. Metzler, and W. Drochner. 2006. Effects of physically effective fiber on digestive processes and milk fat content in early lactating dairy cows fed total mixed rations. J. Dairy Sci. 89:651-668. https://doi.org/10.3168/jds.S0022 $-0302(06) 72129-4$

Zhang, S., R. I. Albornoz, J. R. Aschenbach, D. R. Barreda, and G. B. Penner. 2013. Short-term feed restriction impairs the absorptive function of the reticulo-rumen and total tract barrier function in beef cattle. J. Anim. Sci. 91:1685-1695. https://doi.org/10.2527/ jas.2012-5669. 